\title{
The influence of photoperiod on head formation in some Brachiaria species and Chloris gayana cv. Masaba
}

\author{
J. G. P. Dirven, L. J. M. van Soest * and K. Wind
}

Department of Field Crops and Grassland Husbandry, Agricultural University, Wageningen, the Netherlands

Accepted: 11 August 1978

Key words: Brachiaria, Chloris gayana, photoperiod, head formation

\section{Summary}

The effect of the photoperiod on head formation was investigated in 5 Brachiaria species and selected ecotypes of Chloris gayana cv. Masaba. The experiments were conducted in greenhouses where the grasses were exposed to photoperiods of 10 , 12 and $14 \mathrm{~h}$ in 1971 and 9, $10 \frac{1}{4}$ and $12 \frac{1}{2} \mathrm{~h}$ in 1973. The photoperiods comprised 9 hours natural daylight in the summer, supplemented with $40 \mathrm{~W}$ incandescent lamps.

It is concluded that Brachiaria mutica is a qualitative (obligate) short-day plant whereas B. ruziziensis and Chloris gayana cv. Masaba are quantitative short-day plants. $B$. brizantha and $B$. decumbens were already flowering when exposed to $24 \mathrm{~h}$ photoperiods during the pre-experimental period in 1971. In the Brachiaria introduction PI 299498, head formation in both experiments occured a few days earlier under the short photoperiod treatment. In the later-formed heads of all grasses tested the number of racemes per head decreased, though the length of the racemes was not affected. During the 1971 experiment, culm branching was observed in most of the grasses. It was found that in C. gayana cv. Masaba 'secondary' culms were mainly formed during photoperiods of 10 and $12 \mathrm{~h}$ but rarely by $14 \mathrm{~h}$. 'Tertiary' culms in B. ruziziensis were observed in photoperiods of 10 and 12 h. It is suggested that culm branching can be attributed to high relative humidity. The low seed production of tropical grasses is mainly caused by the low number of heading tillers per unit area and the disynchronization of the flowering resulting from the long period of head production. It is suggested that more research on the photoperiodic response of these grasses would provide useful information on seed production. After selection of photosensitive cultivars and seed production at latitudes of approximately $15^{\circ} \mathrm{N}$ and $15^{\circ} \mathrm{S}$ the long period of heading would be reduced and the synchronization of the flowering would be improved. Some of the

\footnotetext{
* Present address: Institut für Pflanzenbau und Saatforschung (FAL), Bundesallee 50, 3300 Braunschweig, West Germany.
} 
early heading types of $C$. gayana cv. Masaba are typical examples of photosensitive cultivars.

\section{Introduction}

Very little detailed work has been done on photoperiodism in tropical pasture grasses. Broadly speaking, most of these grasses produce heading tillers the whole year round in tropical environments. Reviews by Evans (1964) and Humphreys (1975) reveal that many of these tropical grasses are short-day plants, with only a few grasses flowering when the photoperiod is less than a critical length, while the other species flower more rapidly in short days. These two groups of grasses are called qualitative (obligate) and quantitative short-day plants, respectively. Some tropical grasses such as Paspalum dilatatum and $P$. notatum are classified as obligate long-day plants, although in both grasses flowering occurs at latitude $6^{\circ} \mathrm{N}$ (Surinam). On the other hand Boyce (1970) found that Setaria sphacelata cv. Nandi is most probably a quantitative long-day plant. However, the differences in photoperiodic response of one species in different experiments are most probably the result of the particular ecotype or cultivar used and the treatments during the pre-experimental period.

Even in areas with small differences between the shortest and the longest day, the photoperiodic sensitivity of a particular grass can have important consequences on grassland exploitation. For example, in the coastal region of Surinam $\left(6^{\circ} \mathrm{N}\right.$; differences in daylength of 43 minutes or less) the pasture grasses Ischaemum timorense and Melinis minutiflora flower abundantly about December. At that time the stem percentage of the grass crop increases substantially but few young tillers are produced. Consequently the live weight of the grazing animal will fall.

As stem elongation in tropical grasses occurs continuously and abundantly, even in a young growing stage, the leaf percentage in the aging grass crop will decrease rapidly. Thus, the nutritive value of the grass will be greatly reduced, while the dry matter intake of the animal also decreases. At the same time the production of new tillers, which in such a crop situation are also not easily accessible to the grazing animal, will be reduced. Greater sensitivity of tropical grasses to daylength can result in a restricted period of flowering and this will improve the quality of the grass as well as seed production. The next section will deal with this second aspect of the photoperiod.

\section{The role of heading in seed production}

Seed yields of tropical pasture grasses are generally very low. Boonman (1971), working with 6 tropical grasses in Kenya, mentioned 7 factors that caused low yields. The most important factors were the number of heading tillers per $\mathrm{m}^{2}$, the indeterminate flowering habit and low seed setting of these grasses. However, some of these factors seem to be inherent to the morphological and physiological characteristics of these species. Thus the tiller density of tropical grasses is considerably lower than that of temperate grasses. Consequently, given the same heading per- 
centage in both type of grasses, the number of fertile tillers per unit area will be much lower in tropical grasses. This is clearly illustrated in Table 1, where some components of the seed production of tropical and temperate grasses obtained from well managed experiments, are compared. It is evident that the large difference in seed yield between tropical and temperate grasses are mainly the result of the low number of fertile tillers per $\mathrm{m}^{2}$. The differences in the number of seeds and the seed weight per inflorescence between the tropical and temperate grasses are almost of the same magnitude within both groups. However it should be noticed that the percentage Pure Germinating Seed (\% PGS) of tropical grasses is usually 20-40 whereas it is approximately 90 in temperate grasses.

Seed yields of tropical grasses can be increased by agronomic practices such as nitrogen application and row width, which influence heading. Boonman (1972a, 1972b) conducted experiments on this from 1969 to 1971 (5-6 harvests) with Setaria sphacelata cv. Nandi II and Chloris gayana cv. Mbarara in Kenya. Data on head numbers and seed yields obtained from different treatments are plotted against each other in Fig. 1. In Setaria the highest seed yields (harvested) were attained at 170 heads per $\mathrm{m}^{2}$, whereas in Chloris they were achieved at approximately 300 heads per $\mathrm{m}^{2}$. Boonman (1972a, 1972b) found no significant correlation between head numbers per unit area and average percentage PGS. In Setaria the average \% PGS was 19.5 whereas 39.7 in Chloris. Fig. 1 also shows that an increase in the number of heads resulted in a decrease in seed weight per inflorescence.

It can be concluded from the results quoted that since it is unlikely that the low density of the present assortment of tropical grasses can be improved, higher seed yields will have to be obtained by increasing the number of seeds per head. However, this means improving seed setting. The indeterminate heading habit of these grasses, which are mainly crosspollinating, causes poor synchronization of flowering. This unfavourably affects seed setting, causing it to take place over a long

Table 1. Components of seed yields for some tropical and temperate grasses.

\begin{tabular}{|c|c|c|c|c|c|c|}
\hline Species & $\begin{array}{l}\text { Data } \\
\text { from* }\end{array}$ & $\begin{array}{l}\text { Fertile } \\
\text { tillers } \\
\text { per } \mathrm{m}^{2}\end{array}$ & $\begin{array}{l}\text { Number of } \\
\text { seeds per } \\
\text { inflorescence }\end{array}$ & $\begin{array}{l}\text { 1000-grain } \\
\text { weight (mg) }\end{array}$ & $\begin{array}{l}\text { Seed per } \\
\text { inflorescence } \\
\text { (mg) }\end{array}$ & $\begin{array}{l}\text { Clean seed } \\
(\mathrm{kg} / \mathrm{ha})\end{array}$ \\
\hline $\begin{array}{l}\text { Setaria sphacelata } \\
\text { cv. Nandi II }\end{array}$ & (1) & $40-278$ & $97-224$ & $310-340$ & $33-75$ & $13-99$ \\
\hline $\begin{array}{l}\text { Setaria sphacelata } \\
\text { CPI } 32930 \text { and } 33452\end{array}$ & (2) & $5-166$ & $50-78$ & 833 & $45-65$ & $6-39$ \\
\hline $\begin{array}{l}\text { Chloris gayana } \\
\text { cv. Mbarara }\end{array}$ & (1) & $67-293$ & $83-172$ & $250-290$ & $24-43$ & $16-110$ \\
\hline atense & (3) & $580-845$ & $256-396$ & $297-316$ & $76-125$ & $644-725$ \\
\hline Poa pratensis & (3) & $2127-2617$ & $109-139$ & $219-226$ & $25-31$ & $522-775$ \\
\hline $\begin{array}{l}\text { Lolium perenne } \\
\text { hay type }\end{array}$ & (3) & $1523-1958$ & $27-32$ & $1490-1649$ & $41-52$ & $777-915$ \\
\hline
\end{tabular}

* (1) Boonman (1972a, 1972b); (2) Hacker \& Jones (1971); (3) Evers \& Sonneveld (1954, 1956). 


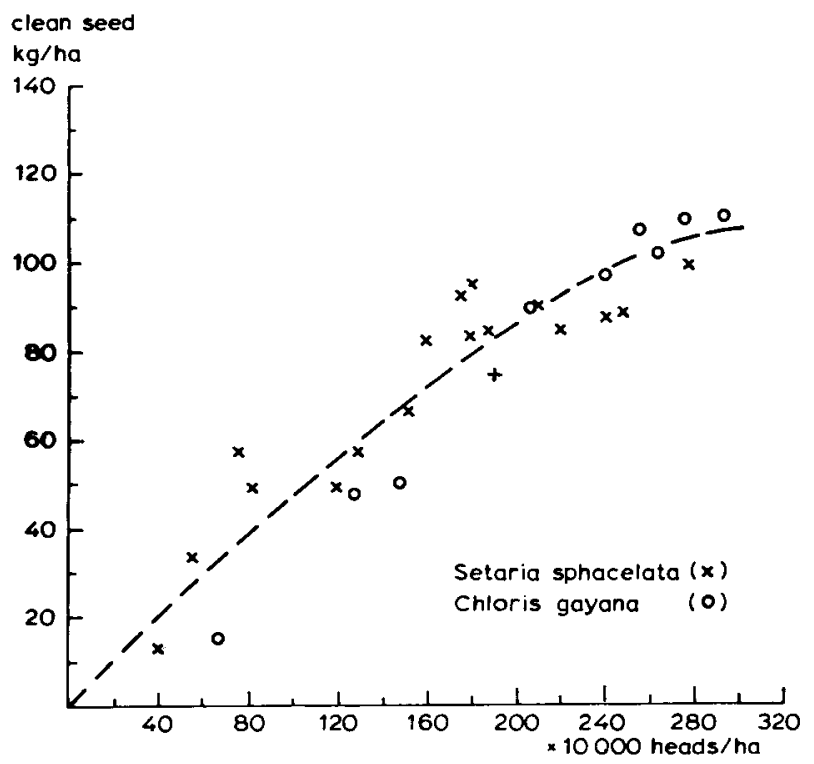

Fig. 1. Relation between number of heading tillers and clean seed yield in Setaria sphacelata and Chloris gayana (data from Boonman, 1972a, 1972b).

period. Consequently, seed shattering occurs particularly in the heads that have emerged early. Roe (1972) estimated that mechanical harvesting can reduce the potential seed yield by more than $40 \%$.

Naturally the question arises how the indeterminate heading habit of tropical grasses can be reduced. Shortening this period would improve seed setting, and seeds would ripen more uniformly.

Every tiller initiated in a tropical grass is usually able to reach the generative stage after a certain period. As soon as a tiller has reached a certain stage of development or has formed a certain number of leaves, it is receptive to a flower stimulus. The initiation of inflorescence will be determined by daylength, although in tropical grasses low night temperatures can inhibit this process. The different growing stages of the tillers in a grass crop and the slight sensitivity of these tropical grasses to photoperiod prolongs the heading. It has often been said that daylength is unlikely to be an important controlling influence in plants in the tropics, where the range of daylength is slight. However, photoperiodic effects found in Oryza sativa and Sorghum vulgare (Best, 1961; Keulemans, 1959) suggest that the small seasonal changes in tropical daylengths may have marked effects on inflorescence initiation.

To gain a better insight into the sensitivity of tropical grasses to daylength an experiment was conducted with some Brachiaria species and C. gayana cv. Masaba material. 


\section{Material and methods}

The first experiment was conducted in the summer of 1971 in temperature-controlled greenhouses. The grasses included were: Brachiaria brizantha (Hochst.) Stapf, $B$. decumbens Stapf, B. mutica (Forsk.) Stapf, B. ruziziensis Germain et Evrard, B. species P.I 299498 USDA and Chloris gayana Kunth.

The Brachiaria species were introduced from Surinam where these grasses have been propagated vegetatively for many years to establish pastures. The introduced material consisted of a few splits and is therefore of a narrow genetic constitution. The $C$. gayana material was selected from the Masaba Foundation Field of the National Agricultural Research Station, Kitale, Kenya (Boonman, 1977). The introductions included splits (clones) and seed material and was described as follows in Kenya:

Clone $1(\mathrm{C} 1)$ - very leafy, early heading type with $200-250$ heads per $\mathrm{m}^{2}$;

Clone 2 (C2) - leafy, early heading type with $150-200$ heads per $\mathrm{m}^{2}$;

Clone 3 (C3) - leafy, medium-late heading type with 150-200 heads per $\mathrm{m}^{2}$;

Seed 1 (S1) - harvested from a leafy, late heading type with 100-150 heads per $\mathrm{m}^{2}$;

Seed 2 (S2) - harvested from a leafy, late heading type with 50-100 heads per $\mathrm{m}^{2}$;

The interval between early and medium-late heading types was 2-3 weeks in Kenya whereas the interval between early and late heading types was 4-5 weeks. Starting from April 1971 the plant material of the Brachiaria species was vegetatively propagated in sand-filled 5-litre plastic pots $\left(300 \mathrm{~cm}^{2}\right.$ surface area). The day and night temperatures prior to the start of the experiment were $29^{\circ} \mathrm{C}$ and $23^{\circ} \mathrm{C}$ respectively. During this period the plants were exposed to a photoperiod of 24 hours, obtained from artificial illumination.

Repeated stem cuttings were made from the C. gayana clones starting from February. The seed material was sown in wooden trays and the seedlings were transplanted 10 days after germination. Multiplication was encouraged by providing day and night temperatures of 25 and $20^{\circ} \mathrm{C}$ respectively and a daylength of $24 \mathrm{~h}$. Mid-April all plants were transplanted to 5-litre plastic pots and kept for one month in a phytotron with $16 \mathrm{~h}$ photoperiod. From mid-May to the start of the experiment ( 28 June) the material was again kept in the greenhouse under a daylength of $24 \mathrm{~h}$.

During the pre-experimental period all grasses were regularly treated with a complete solution of minerals, and clipped to a height of $25 \mathrm{~cm}$. The average radiation $(400-10000 \mathrm{~nm})$ inside the greenhouse during May and June was 1377 $\mathrm{J} \mathrm{cm}^{-2}$ day $^{-1}$. The experiment was started on 28 June, when 2-4 pots of each grass or clone were exposed to photoperiods of 10,12 and $14 \mathrm{~h}$. The photoperiods were made up of 9 hours natural light from 08.00 until 17.00 and supplemented with low intensity light from incandescent lamps $(40 \mathrm{~W})$ for 1,3 and $5 \mathrm{~h}$ respectively. The average radiation inside the greenhouse during the period from 28 June to 20 September was $1046 \mathrm{~J} \mathrm{~cm}^{-2}$ day-1. The average day and night temperatures were 29 and $23{ }^{\circ} \mathrm{C}$ respectively, whereas the average relative humidity was about 
$70 \%$ during the day and $75 \%$ at night.

During the experiment, newly produced heading tillers in at least two pots per treatment were marked with a label showing the date. The appearance of the head through the flag-leaf was used as criterion for heading. The number and the length of the racemes of certain heads were recorded and in the Brachiaria species the number of spikelets per raceme was also counted.

\section{Results and discussion}

The results of the Bracharia species and Chloris gayana will be presented seperately. The former are all different species whereas the latter are selected types of the Masaba variety of Rhodes grass.

\section{Bracharia species}

After a long pre-experimental period (daylength of $24 \mathrm{~h}$ ) the development of $B$. brizantha and $B$. decumbens was already so far advanced that no influence of photoperiod on heading could be expected. At termination date (after 37 days) the same number of heads was counted in both grasses in all three photoperiod treatments. Furthermore the heading curve was similar for both Brachiaria spp. However reactions to different photoperiods were very evident in B. ruziziensis. Initial heading was stimulated by the 10 -h treatment and was also accelerated in the short-day treatments. However, the number of heads per unit area was approximately the same for all treatments at the respective termination days. Fig. 2 presents the cumulative heading curves of these three Brachiaria species.

B. mutica did not produce heads in the 14-h treatment, but shortening the photoperiod from $12 \mathrm{~h}$ to $10 \mathrm{~h}$ resulted in earlier and somewhat accelerated heading. In Brachiaria sp. PI 299498 heading had already occured 10 days after the experjment had commenced. In this grass the first heads were produced a few days earlier in the short-day treatments. At termination date (after 43 days) the number of

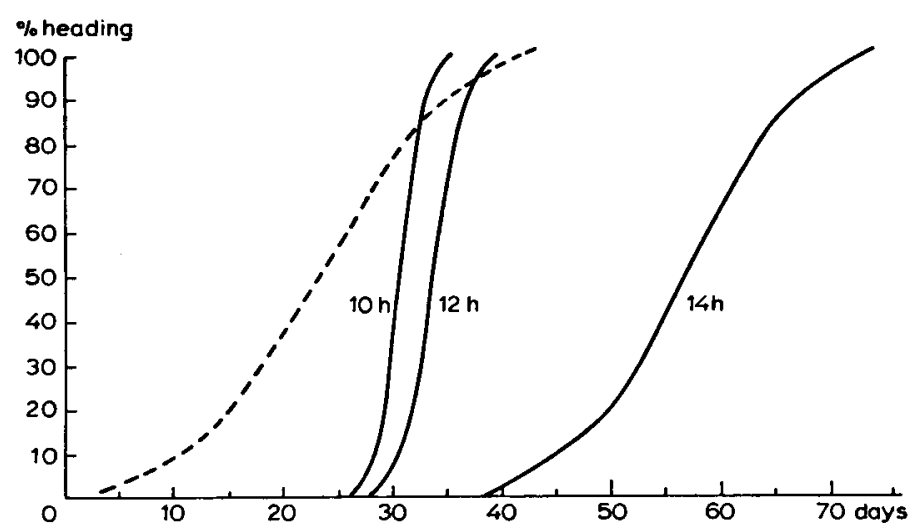

Fig. 2. Cumulative heading curves of three Brachiaria species subjected to different photoperiods (-- - B. brizantha and $B$. decumbens $(10,12,14 \mathrm{~h}) ;-B$. ruziziensis $)$.

Neth. J. agric. Sci. 27 (1979) 
Table 2. Some characteristics of the inflorescences of $B$. brizantha and $B$. decumbens at different dates (averaged from 3 photoperiods).

\begin{tabular}{llllllr}
\hline Species & Date & $\begin{array}{l}\text { Number of } \\
\text { racemes per } \\
\text { inflorescence }\end{array}$ & $\begin{array}{l}\text { Length per } \\
\text { raceme (cm) }\end{array}$ & $\begin{array}{l}\text { Spikelets } \\
\text { per cm }\end{array}$ & $\begin{array}{l}\text { Spikelets } \\
\text { per raceme }\end{array}$ & $\begin{array}{r}\text { Spikelets per } \\
\text { inflorescence }\end{array}$ \\
B. brizantha & 19 July 1971 & 5.3 & 7.0 & 3.4 & 24 & 127 \\
B. decumbens & 3 Aug. 1971 & 3.9 & 8.4 & 2.9 & 24 & 94 \\
& 3 July 1971 & 3.5 & 6.9 & 4.4 & 30 & 105 \\
& 3 Aug. 1971 & 2.6 & 7.2 & 4.2 & 30 & 78 \\
\hline
\end{tabular}

heading tillers in the 14-h treatment was half that produced in each of the 10 -h and 12-h treatments.

In order to confirm the above results an experiment was repeated in 1973 with photoperiods of $9 \mathrm{~h}, 10 \frac{3}{4} \mathrm{~h}$ and $12 \frac{1}{2} \mathrm{~h}$. The experiment was started mid-May and terminated at the end of July (an experimental period of 77 days). During this experiment the average radiation inside the greenhouse was $1235 \mathrm{~J} \mathrm{~cm}^{-2} \mathrm{day}^{-1}$. Average day and night temperatures during the treatment period were 33 and $25^{\circ} \mathrm{C}$ respectively. The grasses were in a younger growing stage at the start of the experiment than was the case in 1971 . Only the time of heading was recorded. The reactions of $B$. brizantha and $B$. decumbens to different photoperiods were similar to the results found in 1971. In both grasses and in all photoperiod treatments the first heads were observed 14 days after the start of the experiment. However, the 9-h photoperiod tended to accelerate heading. Shortening the daylength resulted in an increase in the number of heads in $B$. decumbens, whereas in $B$. brizantha the same number of heading tillers was present in all photoperiodic treatments at termination date.

In $B$. ruziziensis the emergence of the first heads occured later in the $12 \frac{1}{2}-\mathrm{h}$ treatment than in the two shorter photoperiods. In addition, at termination date it was found that the shorter the daylength had been, the more heading tillers had been produced (181 heads per pot in the 9-h treatment compared with 100 heads per pot in the $12 \frac{1}{2}-\mathrm{h}$ treatment). This clearly shows that $B$. ruziziensis is a quantitative short-day plant. In experiments conducted to study the influence of daylength on the nutritive value of $B$. ruziziensis it also appeared that shortening the daylength from $16 \mathrm{~h}$ to $12 \mathrm{~h}$ accelerated heading (Deinum \& Dirven, unpublished results). This agrees with results from Puerto Rico (Vicente-Chandler et al., 1974) where $B$. ruziziensis flowers abundantly during the late autumn.

Heading showed a marked response to daylength in $B$. mutica. In the $12 \frac{1}{2}-h$ treatment no heading tillers were produced, whereas the number of heads in the 9-h treatment at termination date was considerably higher than that in the $11 \frac{3}{4}-h$ treatment. B. mutica should therefore be regarded as a qualitative (obligate) shortday plant and at higher latitudes in the tropics will form its heading tillers in the late autumn.

In Brachiaria sp. PI 299498, initial heading started in the shortest daylength, as 
was found in 1971. However, the total number of heads at termination date varied markedly in all three treatments.

A number of characteristics of the inflorescence were measured in 1971. Since there were no significant responses to photoperiod in B. brizantha and B. decumbens the data obtained from the early and late heading tillers of all three treatments have been averaged and summarized in Table 2 . In both grasses there were more racemes per inflorescence in the heads that had been produced by 19 July, but the racemes of the later heads were longer.

The number of spikelets per $\mathrm{cm}$ decreased in the later-produced heads but the total number of spikelets per raceme was the same in both the early and late heading tillers, indicating some kind of compensating process. This contrasts with the results of Boonman (1972b) who found fewer and shorter racemes per head in later produced inflorescences of Chloris gayana cv. Mbarara. However, his results were obtained from field trials in Kenya whereas our data are from pot experiments in greenhouses.

In both Brachiaria spp. there were $26 \%$ fewer spikelets per inflorescence in the late heading tillers. In $B$. ruziziensis, short days ( $10 \mathrm{~h}$ and $12 \mathrm{~h}$ daylength) appeared to reduce both the number of racemes per inflorescence and the length of the racemes of the late heading tillers. However, no such differences in the raceme characteristics of early and late heading tillers were found in the 14-h treatment.

Potential seed yields can be calculated from the data obtained from the Brachiaria species studied. Under field conditions assuming 400 heading tillers per $\mathrm{m}^{2}$, 100 spikelets per inflorescence and a 1000 -grain weight of $1930 \mathrm{mg}$ it is possible to calculate a seed yield of $772 \mathrm{~kg} / \mathrm{ha}$ for B. ruziziensis. In Kenya, Boonman \& van Wijk (1973) obtained an average PGS yield of $23 \mathrm{~kg} / \mathrm{ha}$ in this grass (a recovery of $3 \%)$. In Setaria sphacelata Hacker \& Jones (1971) reported a calculated recovery of the potential seed yield of 5-7\%.

In both experiments $(1971,1973)$ we observed the phenomenon of culm branching in $B$. brizantha and $B$. decumbens. In $B$. ruziziensis 'tertiary' culms were even noticed. 'Secondary' culms develop out of elevated nodes in the parental culm and are able to form inflorescences. Boonman (1971b) noticed this phenomenon in Panicum coloratum and Setaria sphacelata cv. Nandi in Kenya. In Surinam culm branching has also been observed in $P$. coloratum and $B$. decumbens. In the Netherlands this phenomenon was noticed as early as 1919 by Hessing in Lolium multiflorum Lamk. and by ten Rodengate Marissen (1923) in Panicum miliaceum and Phalaris canariensis during rainy summers. The culm branching in our experiment was most probably caused by high relative humidities and an optimal supply of nutrients. The highest numbers of 'secondary' culms per parental culm counted in $B$. brizantha, $B$. decumbens and $B$. ruziziensis respectively were 4,2 and 7 . In the latter grass a maximum of 6 'tertiary' culms was observed. On average, the period between the heading of the parental and 'secondary' culms was 14 days. However, in some tillers of $B$. ruziziensis this period was only two days. 'Tertiary' culms were observed in this grass approximately 14 days after the appearance of 'secondary' heading tillers. The sequence in which the nodes of the parental tiller produced 'secondary' culms was very variable. However, the 'tertiary' culms were 


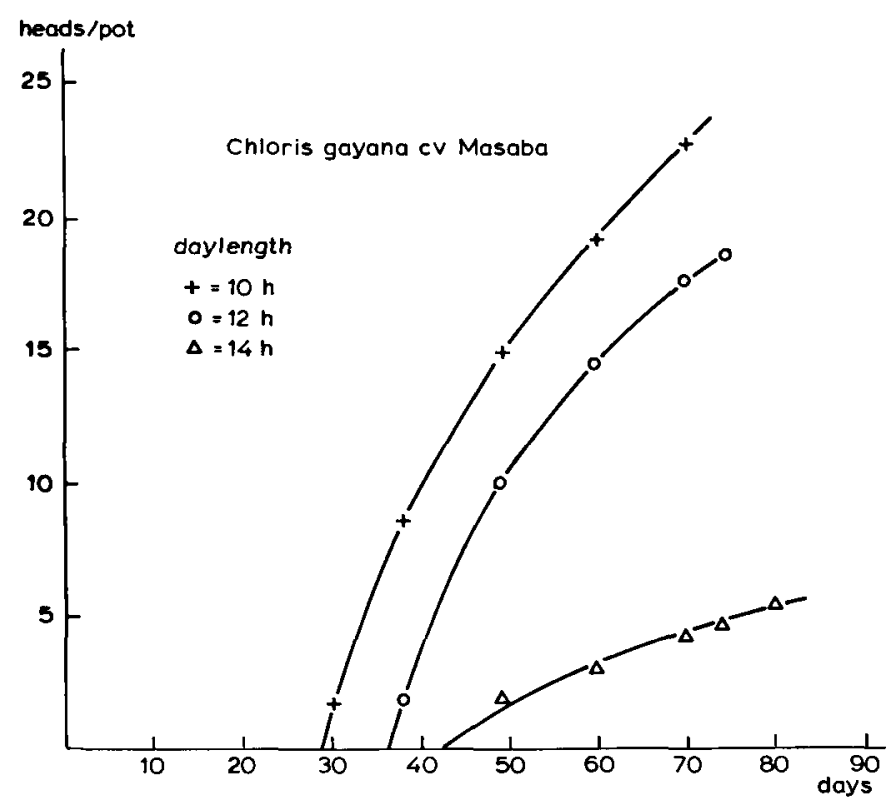

Fig. 3. Effect of three photoperiods on the heading of the total Chloris gayana cv. Masaba material.

always observed first at the top node of the secondary' culm. The average number of racemes per head decreased from 'primary' to 'tertiary' heading tillers, but in all types of heads, raceme length was approximately the same.

\section{Chloris gayana cv. Masaba}

Before the start of the experiment the numbers of tillers per pot in each treatment was counted. Microscopic analysis of several growing points of the shoots before the experiment began revealed that all the grasses were still vegetative. Recording of the 10-h, 12-h and 14-h treatments was terminated on 6,10 and 20 September 1971, i.e. 70,74 and 84 days respectively after the start of the experiment.

The influence on the 3 photoperiods on the heading of all the material (clones + seed) is summarized in Fig. 3. It is evident from the curves that an increase in the photoperiod results in a marked delay in initial heading. In addition, Fig. 3 clearly shows that the total number of heads per pot is highest in the 10-h treatment.

It is of interest to note that in the 10 -h photoperiod treatment $65 \%$ of the heading tillers recorded at termination date were already present after 3 weeks; obviously this improves the synchronization of flowering and consequently results in higher seed yields.

The curve of the 12 -h photoperiod echoes that of the $10-\mathrm{h}$ photoperiod, but at a lower level. In the 14-h treatment the decrease in heading is spectacular. In view of the selection of flowering time and head density in the Masaba foundation field in Kenya it was anticipated that there would be differences in photoperiodic reac- 
Table 3. The number of heading tillers of different clones and seed material of Chloris gayana cv. Masaba subjected to 3 photoperiods, expressed as percentages of the number of vegetative tillers present at the start of the experiment in 1971.

\begin{tabular}{lrrr}
\hline Length of photoperiod (h) & 10 & 12 & 14 \\
Duration of experiment (days) & 70 & 74 & 84 \\
C1 & 114 & 96 & 46 \\
C2 & 122 & 75 & 33 \\
C3 & 88 & 56 & 15 \\
S1 & & 37 & 0 \\
S2 & & 41 & 0 \\
\hline
\end{tabular}

tion. At the start of the experiment there were some differences between the number of tillers per pot of the clones and the seed material. Therefore the number of heads at termination date were expressed as percentages of the total number of tillers (Table 3).

The differences in number of heads produced by the different clones and seed material used in this experiment were similar to results found in the Masaba foundation fields in Kenya (Boonman, 1977). The number of heads produced was found to decrease in sequence from $C_{1}$ to $S_{2}$ and this was accompanied by a delay in flowering and a lower head density per $\mathrm{m}^{2}$. In our experiment increase in photoperiod produced a decrease in heading in all materials. No heading tillers were produced in the plants obtained from seeds $\left(S_{1}\right.$ and $\left.S_{2}\right)$ that were subjected to a photoperiod of $14 \mathrm{~h}$. The differences between clones were more pronounced as photoperiod was lengthened.

From these results it was concluded that Chloris gayana cv. Masaba is a quantitative short-day plant. However, the reaction of the grass to a daylength between 10 and $12 \mathrm{~h}$ was still unclear and it was not certain that heading would be delayed in photoperiods shorter than $10 \mathrm{~h}$. Therefore, a similar experiment was repeated in 1973, but only clones 1,2 and 3 were exposed to photoperiods of $9,10 \frac{3}{4}$ and $12 \frac{1}{2} \mathrm{~h}$ respectively. The experiment was conducted under the same growing conditions already described for the Brachiaria spp. in 1973. However, at the start of the experiment the grasses were in an earlier growing stage than was the case in the 1971 experiment. In Table 4 the total numbers of heads per pot at termination date (after 77 days) are summarized.

There were no significant differences in photoperiodic response between the

Table 4. The number of heading tillers per pot of 3 clones of Chloris gayana cv. Masaba subjected to three photoperiods in 1973.

\begin{tabular}{lccc}
\hline Clone & \multicolumn{2}{c}{ Photoperiod length (hours) } \\
\cline { 2 - 4 } & 9 & $10 \frac{3}{4}$ & $12 \frac{1}{2}$ \\
C1 & 55 & 53 & 0 \\
C2 & 35 & 43 & 1 \\
C3 & 35 & 36 & 4 \\
\hline
\end{tabular}

Neth. J. agric. Sci. 27 (1979) 
photoperiods of 9 and $10 \frac{3}{4} \mathrm{~h}$. As was found in 1971, clone 1 produced the highest number of heads; this corresponds with van Soest's (1973) findings at Kitale, Kenya $\left(1^{\circ} \mathrm{N}\right)$. The time of initial head emergence decreased in sequence from clone 1 to clone 3 . After approximately 40 days the percentage of total tillers that had heads was $43 \%, 22 \%$ and $5 \%$ for clones 1,2 and 3 respectively. This was calculated in using the mean of the tillers from the 9 -h and $10 \frac{3}{4}-\mathrm{h}$ treatment. Some days before the termination of the experiment a few heading tillers were observed in the $12 \frac{1}{2}-\mathrm{h}$ photoperiod: the young growing stage of these plants at the start of the experiment may have delayed their photoperiodic introduction.

In the 1971 experiment the number of racemes per head in the 10-h and 12-h treatments decreased in later-formed heading tillers. Boonman (1972b) found the same phenomenon in C. gayana cv. Mbarara. However this was not found in the 14-h treatment and may therefore be ascribed to the delayed heading which resulted in a higher total light intensity for the tillers.

The phenomenon of culm branching already found in the Brachiaria species was also observed in $C$. gayana cv. Masaba. The number of 'secondary' culms that elongated from the main tiller varied from 1 to 7 . The sequence in which the nodes of the parent tiller formed 'secondary' culms was very variable. There were fewer racemes per head in the 'secondary' heads than in the 'primary' heads. The length of the racemes of both types of heads did not differ significantly.

\section{Conclusion}

It is a fact that the low seed production of tropical pasture grasses is mainly due to the low number of fertile tillers per unit area. This is a direct consequence of the low tiller-density of tropical grasses. However it is unlikely that tiller-density can be improved, and therefore higher seed yields will only be obtained if more seeds are formed per inflorescence. The prolonged head emergence of these grasses, however, results in a disynchronization of flowering and there is a need for more photosensitive cultivars that have a restricted flowering period. The results of our experiments indicate that Brachiaria mutica is a qualitative (obligate) short-day plant whereas $B$. ruziziensis and Chloris gayana $\mathrm{cv}$. Masaba are quantitative shortday plants. This latter variety of Rhodes grass has early and late heading types in Kenya which show marked differences in photoperiodic response.

It is suggested that to improve the seed yields of tropical grasses, such photoperiod-sensitive cultivars should be cultivated in areas with pronounced differences in daylength during the growing season. The length of the shortest day in the winter at latitudes $23^{\circ} \mathrm{N}$ and $23^{\circ} \mathrm{S}$ is approximately $10 \frac{1}{2} \mathrm{~h}$, whereas that of the longest day in the summer is $13 \frac{1}{2} \mathrm{~h}$. However, near these latitudes the winter temperatures are too low to grow tropical grasses successfully. It may therefore be advisable to commence commercial seed production of these types of grasses at latitudes of approximately $15^{\circ} \mathrm{N}$ and $15^{\circ} \mathrm{S}$. By carefully choosing the time when the cleaning cut is made, a restricted period and synchronization of flowering can be achieved, which will result in higher seed yields. 


\section{References}

Best, R., 1961. Some aspects of photoperiodism in rice (Oryza sativa L.). Thesis, Wageningen, $87 \mathrm{pp}$.

Boonman, J. G., 1971a. Experimental studies on seed production of tropical grasses in Kenya. 1. General introduction and analysis of problems. Neth. J. agric. Sci. 19: 23-36.

Boonman, J. G., 1971b. Experimental studies on seed production of tropical grasses in Kenya. 2. Tillering and heading in seed crops of eight grasses. Neth. J. agric. Sci. 19: 237-249.

Boonman, J. G., 1972a. Experimental studies on seed production of tropical grasses in Kenya. 3. The effect of nitrogen and row width on seed crops of Setaria sphacelata cv. Nandi II. Neth. J. agric. Sci. 20: 22-34.

Boonman, J. G., 1972b. Experimental studies on seed production of tropical grasses in Kenya. 4. The effect of fertilizers and planting density on Chloris gayana cv. Mbarara. Neth. J. agric. Sci. 20: 218-224.

Boonman, J. G., 1977. On Rhodes grass breeding, seed yield and herbage quality. Technical report G B P June/77/1. National Agricultural Research Station, Kitale, Kenya, 61 pp.

Boonman, J. G. \& A. J. P. van Wijk, 1973. The breeding for improved seed and herbage production. Neth. J. agric. Sci. 21: 12-23.

Boyce, K. G., 1970. Floral initiation and anthesis in Setaria anceps Stapf. M. Agric. Sc. Thesis, University Adelaide.

Evans, L. T., 1964. Reproduction. In: Grasses and Grasslands. Macmillan, London, p. 126-153.

Evers, A. \& A. Sonneveld, 1954. Graszaadteeltproeven. II. Gestencilde Mededeling CILO No 9, Wageningen, $47 \mathrm{pp}$.

Evers, A. \& A. Sonneveld, 1956. Graszaadteeltproeven. III. Gestencilde Mededeling CILO No 6, Wageningen, $50 \mathrm{pp}$.

Hacker, J. B. \& R. J. Jones, 1971. The effect of nitrogen fertilizer and row spacing on seed production in Setaria sphacelata. Trop. Grasslds 5: 61-73.

Hessing, J., 1919. Mitteilungen bezüglich der Variabilität einiger Grasarten. Z. PflZüchtung 7: 53-57.

Humphreys, L. R., 1975. Tropical pasture seed production. FAO, Rome, Italy, 115 pp.

Keulemans, N. C., 1959. Photoperiodiciteit bij Sorghum vulgare Pers. Thesis, Wageningen, $107 \mathrm{pp}$.

Rodengate Marissen, J. Z. ten, 1923. Bijzondere plantenteelt. I. Bouwland, 3e druk. Wolters, Groningen, $158 \mathrm{pp}$.

Roe, R., 1972. Seed losses with different methods of harvesting. Trop. Grasslds 6: 113-118.

Soest, L. J. M. van, 1973. Photoperiodiciteit bij Chloris gayana Kunth. Dissertation, Wageningen, $38 \mathrm{pp}$.

Vicente-Chandler, J., F. Abruña, R. Caro-Costas, J. Figarella, S. Silva \& R. W. Pearson, 1974. Intensive grassland management in the humid tropics of Puerto Rico. Bull. Agric.Exp. Stn Rio Piedraz, Puerto Rico No 233; 164 pp. 